\title{
EFFECTS OF COMPLEMENTARY AND EXCESS DIET SUPPLEMENTATION WITH SELECTED MINERALS ON THEIR METABOLISM AND DISTRIBUTION IN THE BODY: A MODEL STUDY
}

\author{
Mariola Friedrich, Grażyna Podlaszewska, Kamila Pokorska-Niewiada \\ Department of Human Nutrition Physiology, West Pomeranian University of Technology \\ Papieża Pawła VI/3, 71-459 Szczecin, Poland
}

\begin{abstract}
Introduction. The study was aimed at determining, on an animal model, effects of supplementing a diet, modified by substituting whole wheat and corn grains with white flour and sucrose, with calcium, magnesium, zinc, and chromium on metabolism of the minerals and their distribution in the body.

Material and methods. The study involved 4 groups of Wistar rat females $(n=11)$ fed: a standard feed (group I) containing, i.a., whole wheat and corn grains; modified feed (84\% and $50 \%$ of whole wheat and corn grains, respectively, in the standard feed substituted with Type 500 wheat flour and sucrose, respectively) (group II); modified feed with complementary supplementation (elimination of $\mathrm{Ca}, \mathrm{Mg}, \mathrm{Zn}$, and $\mathrm{Cr}$ deficiencies resulting from diet modification) (group III); and modified feed with excess supplementation (the same minerals applied in excess, i.e., amounts from 0.5 to 3 times higher than the deficiencies produced by diet modification) (group IV). The replacement of whole grains with white flour and sucrose, as well as the mineral supplementation could, to some extent, imitate the contemporary eating habits and supplementation applied in food technology. The excess supplementation is, on the other hand, typical of current behaviours of various social groups.

Results. Both types of supplementation resulted in a significant increase in the perivisceral adipose tissue content, but did not affect the fat tissue content in muscles. The supplementation applied did not change the content of calcium, magnesium, and zinc in muscles, nor did it significantly change calcium and magnesium excretion with urine. However, changes in the ALP activity and calcitonin concentration did not suggest the deposition of the minerals in bones.

Conclusions. Analysis of the results allowed to conclude that: 1) except for chromium, contents of the selected minerals in the tissues examined and urea, as well as concentrations of calcitonin and alkaline phosphatase (ALP) activities did not point to any significant effect of the supplementation applied on the body contents of those minerals; 2) effects observed as the accumulation of perivisceral, epicardial and intramuscular adipose tissue, as well as increased body weight increments could have been related to disturbed proportions of the minerals supplemented, their synergy and antagonism and, consequently, a potential generation of secondary deficiencies and excesses which could significantly affect individual metabolic pathways; 3 ) the intensity of changes observed was generally higher in the females receiving complementary supplementation, although their uptake of minerals studied was similar to that shown by the females kept on the standard diet.
\end{abstract}

Key words: supplementation, minerals, metabolism, rat females 


\section{INTRODUCTION}

Results of current research on the assessment of eating habits show that, regardless of increasing education in and awareness of healthy nutrition, application of the knowledge gained leaves a lot to be desired. Particularly worrisome is the insufficient consumption of vegetables and fruits, and hence vitamins and minerals (particularly calcium, magnesium, iron, copper, zinc, and potassium) (Bolesławska et al., 2005).

A way to improve the quality of nutrition in this respect is sought in supplementation (fortification) by food manufacturers of selected foods with minerals officially approved by the Minister of Health in Directive of 16 September 2010 which adopts the Directive 1925/2006 of the European Parliament and Council of 20 December 2006 and/or dietary supplementation by the consumer, without medical consultation.

This study was prompted by the increase in the number of supplemented (fortified) foods in Poland, demonstrated by the relevant research, which also shows that the proportion of population consuming fortified foods and/or applying diet supplementation has increased as well (Kunachowicz and Troszczyńska, 2005; Szponar and Stoś, 2004).

This study was aimed at determining, on an animal model, effects of dietary supplementation on metabolism of selected minerals and their distribution in the body. In the diet, whole wheat and corn grains were replaced by white flour and sucrose. The diet was supplemented with selected minerals added at amounts eliminating the deficiencies resulting from the replacement (complementary supplementation) or at amounts higher than necessary to eliminate the deficiency (excess supplementation).

The replacement of whole grains with white flour and sucrose, as well as the mineral supplementation could, to some extent, imitate the contemporary eating habits and supplementation applied in food technology. The excess supplementation is, on the other hand, typical of current behaviours of various social groups (Bolesławska et al., 2005). The selection of minerals to be added to the diet was dictated by their physiological role, dietary and body deficiencies and the fact that they were approved for fortification and/or are most often used as human diet supplements $(\mathrm{Ku}-$ nachowicz and Troszczyńska, 2005).

\section{MATERIAL AND METHODS}

Following the consent of the Local Ethical Commission (Consent No. 7/2008), the experiment was carried out on 44 Wistar laboratory rat females of $235 \pm 19.8$ $\mathrm{g}$ initial individual weight, aged 5-6 months. The rats were kept individually in metal cages, in an air-conditioned vivarium in which the temperature was kept at $21 \pm 1^{\circ} \mathrm{C}$; the $12 \mathrm{~h} / 12 \mathrm{~h}$ light/dark regime was maintained throughout the experiment.

The rats were divided into 4 treatment groups of $\mathrm{n}=$ 11 each; the mean individual weight in each group was similar They were fed ad libitum feeds consisting of identical components, in addition to the experimental ones, manufactures by Wytwórnia Pasz i Koncentratów in Kcynia, operating under the implemented procedure 5.14.5 ("Equipment Cleaning"). Group I rats were fed a standard Labofeed B diet containing, i.a., whole wheat and corn grains. Group II rats received a modified feed in which about $84 \%$ of whole wheat grains were replaced by Type 500 wheat flour, $50 \%$ of corn grains being replaced by sucrose. Group III rats were administered the modified feed supplemented with $\mathrm{Ca}$, $\mathrm{Mg}, \mathrm{Zn}$, and $\mathrm{Cr}$ to eliminate the deficiencies resulting from diet modification (complementary supplementation). Group IV rats were fed the modified feed supplemented with excess amounts of the same minerals, the amounts added being $0.5-3$ times in excess of the amounts needed to eliminate the deficiencies (excess supplementation). The mineral supplementation applied was modelled, to a certain degree, on the supplementation rates in humans (Bolesławska et al., 2005; Lorenzen et al., 2006; Mazurek-Mochol and Mochoy-Mokrzyńska 2005). The remaining diet components were present in the feeds in identical amounts.

The feeds were analysed for their basic chemical components. According to the recommended methodology (Gawęcki and Jeszka, 1995), $4 \mathrm{~g}$ feed samples were analysed for crude protein, raw fat, dry matter and minerals (as total ash; Table 1). The feeds were isocaloric.

The content of non-soluble dietary fibre was determined with the detergent technique of Van Soest and Wine (1967) in an ANKOM 220 apparatus (Table 2).

Contents of calcium, magnesium, zinc, and chromium in the feeds used were determined with atomic emission spectroscopy using an ICP-AES Jobin Yvan JY apparatus (Table 3). 
Friedrich, M., Podlaszewska, G., Pokorska-Niewiada, K. (2015). Effects of complementary and excess diet supplementation with selected minerals on their metabolism and distribution in the body: a model study. Acta Sci. Pol. Technol. Aliment., 14(2), $165-174$. DOI: 10.17306/J.AFS.2015.2.18

Table 1. Chemical composition of feeds

\begin{tabular}{lcc}
\hline \multicolumn{1}{c}{ Component } & Basic feed & Modified feed \\
\hline Total protein, \% & 19.16 & 18.48 \\
Crude fat, \% & 2.81 & 2.33 \\
Carbohydrates, \% & 63.76 & 65.46 \\
Dry matter, \% & 91.84 & 92.26 \\
Total ash, \% & 6.09 & 5.98 \\
Gross energy & & \\
$\quad$ kcal/g & 3.99 & 3.98 \\
$\quad$ kJ/g & 16.73 & 16.67 \\
Metabolic energy & & \\
kcal/g & 3.57 & 3.56 \\
kJ/g & 14.95 & 14.94 \\
\hline
\end{tabular}

Table 2. Contents of insoluble fibre fractions in feeds used in the experiment, \% d.m.

\begin{tabular}{lcc}
\hline \multicolumn{1}{c}{ Component } & Basic feed & Modified feed \\
\hline Cellulose & 6.02 & 5.67 \\
Hemicellulose & 10.31 & 5.69 \\
NDF & 17.82 & 12.67 \\
ADF & 7.51 & 6.98 \\
ADL & 1.42 & 1.31 \\
\hline
\end{tabular}

NDF - neutral-detergent fibre, ADF - acid-detergent fibre, $\mathrm{ADL}$ - lignin.

Table 3. Contents of minerals studied in feeds used in the experiment, $\mathrm{mg} / \mathrm{kg}$

\begin{tabular}{lcccc}
\hline \multicolumn{1}{c}{ Feed } & Calcium & Magnesium & Zinc & Chromium \\
\hline Basic & 12293 & 1790 & 120.0 & 0.451 \\
Modified & 11406 & 796 & 105.7 & 0.209 \\
\hline
\end{tabular}

Group I and II rats drank clean tap water left to stand; at the time of intensified activity, group III and IV rats were given $30 \mathrm{ml}$ doses of aqueous solutions of minerals in the form of calcium gluconate (Farmapol Sp. z o.o.), magnesium hydrocarbonate (Polfa
Sp. z o.o.), zinc gluconate (Walmark), and amino acid chromium chelate (Naturell AB). The amount of minerals, calculated relative to the amount of the daily feed ration, was - in group III - compensating for the difference in the mineral composition between the standard and modified feeds; in group IV, the amount of minerals exceeded the difference: the amounts of calcium, magnesium, zinc, and chromium were $0.5 \times$, $3 \times, 2 \times$, and $3 \times$ higher, respectively (excess supplementation). Once the animals drank the solution of minerals, their liquid intake was supplemented by clean tap water left to stand.

In week 6, the rats were placed in Techniplast metabolic cages. Following 48-h conditioning, the urine was collected for $24 \mathrm{~h}$ and analysed.

During the 7 weeks of the experiment (following a 1 week conditioning), the amounts of minerals taken up and feed consumed were calculated daily. The animals were weighed once a week, always at the same time. Twelve hours before the experiment was due to be terminated, the feeding ceased and the animals were put to sleep using a Ketanest anaesthetic intramuscular injection. The cardiac blood was then sampled for assays.

The total blood serum concentrations of calcium (colorimetrically, with o-cresolophthalein), magnesium (colorimetrically, with chlorophosphoonazo III), inorganic phosphorus (with phosphomolybdenate), and alkaline phosphatase (ALP) activity (kinetic method, with p-nitrophenylphosphate) were determined. The assays were performed in a closed system (COBAS INTEGRA 400/700/800 apparatus), using Roche Diagnostics reagents. The calcitonin concentration was determined by the two-score immunoenzymatic test with chemiluminescence. The same methods were used to determine urinary concentrations of calcium and magnesium.

The muscle tissue (from $m$. quadriceps femoris, $m$. semimembranosus, $m$. adduktor femoris, $m$. superficialis gluteus) was analysed for crude protein (the Kjeldahl method), fat (the Soxhlet methods), dry matter (drying to constant weight), ash content (combustion to constant weight), and contents of calcium, magnesium, zinc, and chromium (emission spectrometry ICP OES. Each assay was performed in triplicate.

The perivisceral fat content was determined by weighing, to $0.001 \mathrm{~g}$, the fat removed immediately after the animals were sacrificed. 
The data, checked for normality of distribution, were subject to multivariate analysis of variance and the Least Significance Difference (LSD) test at significance levels $\mathrm{p} \leq 0.05$ and 0.01 , using the Statistica ${ }^{\circledR}$ software.

\section{RESULTS AND DISCUSSION}

The analysis of effects of the minerals used in the experiment on feed consumption showed no betweengroups differences in feed uptake. However, the conversion of the feed uptake to consumption per unit body weight showed the females supplemented in excess to have consumed significantly less feed than the females fed the standard feed. The difference was reflected in body weight gains which were lowest and significantly lower than those in the rats kept on the non-supplemented modified feed (Table 4). The difference was seen both in absolute values and in weight gain per unit feed consumed.
The effect observed is consistent with the currently held views on mechanisms of calcium and chromium effects on lipogenesis and lipolysis (Heaney et al., 2003; Lorenzen et al., 2006). However, the lower weight gains were accompanied by a significant increase in the amount of the perivisceral adipose tissue, observed in both groups fed the supplemented feeds, although the mineral consumption, particularly that of calcium and chromium, was comparable with, or higher than, that shown by the standard feed-kept rats (Table 5).

It seems that the accumulation of the perivisceral fat observed could have resulted from calcium ionmediated stimulation of adipocytes and an increased autocrine cortisol synthesis, the relevant cortisol effects being already well-known. Such a mechanism seems to be consistent with results of earlier studies (Podlaszewska et al., 2009). On the other hand, increased accumulation of the visceral adipose tissue in those females supplemented in excess could have been

Table 4. Effects of diet and supplementation on diet intake, body weight increments and amount of perivisceral fat tissue $(\mathrm{x} \pm \mathrm{SD}, \mathrm{n}=44)$

\begin{tabular}{|c|c|c|c|c|c|}
\hline Parameter & $\begin{array}{l}\text { Basic feed } \\
\text { (a) }\end{array}$ & $\begin{array}{l}\text { Modified } \\
\text { feed } \\
\text { (b) }\end{array}$ & $\begin{array}{l}\text { Modified feed } \\
+ \text { fortification } \\
\text { (c) }\end{array}$ & $\begin{array}{l}\text { Modified feed } \\
+ \text { suplementation } \\
\text { (d) }\end{array}$ & $\begin{array}{l}\text { Significance of } \\
\text { differences }\end{array}$ \\
\hline Consumption of feed, $g$ & $626.9 \pm 32.8$ & $622.4 \pm 55.1$ & $611.9 \pm 27.8$ & $588.6 \pm 34.0$ & - \\
\hline $\begin{array}{l}\text { Consumption of feed } \\
g / 100 \text { of body mass }\end{array}$ & $257.1 \pm 8.9$ & $253.3 \pm 22.3$ & $249.3 \pm 17.6$ & $244.7 \pm 7.5$ & $a-d^{*}$ \\
\hline Body mass gain, $g$ & $5.14 \pm 3.95$ & $8.41 \pm 2.35$ & $5.18 \pm 3.95$ & $2.34 \pm 3.50$ & $b-d^{* *}$ \\
\hline $\begin{array}{l}\text { Body mass gain } \\
\mathrm{g} / 100 \mathrm{~g} \text { feed consumed }\end{array}$ & $0.79 \pm 0.93$ & $1.35 \pm 0.37$ & $0.84 \pm 0.63$ & $0.39 \pm 0.60$ & $b-d^{*}$ \\
\hline Pericardial fat, $g$ & $0.279 \pm 0.06$ & $0.277 \pm 0.08$ & $0.311 \pm 0.08$ & $0.253 \pm 0.07$ & - \\
\hline $\begin{array}{l}\text { Pericardial fat } \\
\mathrm{g} / 100 \mathrm{~g} \text { feedstuff }\end{array}$ & $0.045 \pm 0.011$ & $0.044 \pm 0.009$ & $0.051 \pm 0.013$ & $0.043 \pm 0.011$ & - \\
\hline $\begin{array}{l}\text { Pericardial fat } \\
\mathrm{g} / 100 \mathrm{~g} \text { body weight }\end{array}$ & $0.114 \pm 0.024$ & $0.112 \pm 0.028$ & $0.127 \pm 0.034$ & $0.104 \pm 0.026$ & $c-a, b, d^{* *}$ \\
\hline Perivisceral fat, $\mathrm{g}$ & $2.14 \pm 0.4$ & $2.23 \pm 0.03$ & $3.07 \pm 0.4$ & $2.39 \pm 0.4$ & $\mathrm{c}-\mathrm{a}, \mathrm{b}, \mathrm{d}^{* *}$ \\
\hline $\begin{array}{l}\text { Perivisceral fat } \\
\mathrm{g} / 100 \mathrm{~g} \text { feed }\end{array}$ & $0.342 \pm 0.070$ & $0.360 \pm 0.032$ & $0.380 \pm 0.025$ & $0.407 \pm 0.064$ & $\begin{array}{l}\mathrm{d}-\mathrm{a}, \mathrm{b}, \mathrm{c}^{* *} \\
\mathrm{c}-\mathrm{a}, \mathrm{b}^{* *}\end{array}$ \\
\hline $\begin{array}{l}\text { Peri-intestinal fat } \\
\mathrm{g} / 100 \mathrm{~g} \text { body weight }\end{array}$ & $0.878 \pm 0.175$ & $0.907 \pm 0.065$ & $1.249 \pm 0.165$ & $0.993 \pm 0.143$ & $c-a, b, d^{* *}$ \\
\hline
\end{tabular}

$*, * *$ Difference significant at $\mathrm{p} \leq 0.05$ and $\mathrm{p} \leq 0.01$, respectively. 
Friedrich, M., Podlaszewska, G., Pokorska-Niewiada, K. (2015). Effects of complementary and excess diet supplementation with selected minerals on their metabolism and distribution in the body: a model study. Acta Sci. Pol. Technol. Aliment., 14(2), $165-174$. DOI: 10.17306/J.AFS.2015.2.18

Table 5. Approximate consumption of selected minerals, resulting from the difference in feed composition, type of supplementation, and uptake magnitude, converted to $100 \mathrm{~g}$ female rat body weight $(\mathrm{x} \pm \mathrm{SD}, \mathrm{n}=44)$

\begin{tabular}{lcccc}
\hline $\begin{array}{c}\text { Component } \\
\text { mg }\end{array}$ & $\begin{array}{c}\text { Basic feed } \\
\text { (a) }\end{array}$ & $\begin{array}{c}\text { Modified feed } \\
\text { (b) }\end{array}$ & $\begin{array}{c}\text { Modified feeds } \\
+ \text { supplementation } \\
\text { (c) }\end{array}$ & $\begin{array}{c}\text { Modified feed } \\
+ \text { supplementation } \\
\text { (d) }\end{array}$ \\
\hline Calcium & $3160 \pm 405$ & $2889 \pm 256$ & $3065 \pm 221$ & $4189 \pm 137$ \\
Magnesium & $460.2 \pm 16.1$ & $201.6 \pm 18.1$ & $446.2 \pm 32.2$ & $587.3 \pm 19.2$ \\
Zinc & $30.85 \pm 1.10$ & $26.77 \pm 2.38$ & $29.92 \pm 2.16$ & $51.88 \pm 1.70$ \\
Chromium & $0.1159 \pm 0.0040$ & $0.0529 \pm 0.0047$ & $0.1124 \pm 0.0081$ & $0.1534 \pm 0.0050$ \\
\hline
\end{tabular}

additionally related to the reduced feed consumption and the resultant reduced uptake of antioxidants such as selenium, vitamin E, phenolic acids, lycopene, zeaxanthin etc., occurring naturally in whole wheat and corn grains (Zieliński et al., 2012).

As already demonstrated in numerous studies, a diet containing easily digestible and absorbable carbohydrates results in an increased intensity of free radical processes by virtue of enhancing glucose metabolism rate. This is induced by, i.a., intensified activity of glutathion peroxidase responsible for catalysing reduction of lipid hyperoxides synthesised with glutathion involvement (Comhair and Erzurun, 2005). A reduced consumption of natural antioxidants and a decreased activity of glutathion peroxidase enhance intensification of fatty lipid oxidation, which reduces the sensitivity of cell membrane to insulin, stimulates glyconeogensis and triacylglycerol biosynthesis (Friedrich et al., 2011; Steinbrenner et al., 2006), triacylglycerols being an independent factor in the increased intensification of free radical processes; this way, the cycle is completed (Olusi, 2002).

Analysis of the perivisceral fat tissue accumulation in those animals supplemented with chromium makes it difficult to endorse a view that chromium applied as a supplement reduces the body's fat tissue. Few studies only revealed chromium supplementation, compared to the placebo, being capable of reducing the body's fat content (Anderson, 1998). Most studies showed no such effects (Balk et al., 2007; Joseph and Umbright, 2008; Lukaski et al., 2007; Olusi, 2002), and this study, too, failed to provide the supporting evidence.
As the body weight and its gains in adults depend primarily on the body's adipose tissue content, the body composition of the rats used in the experiment was analysed. The analysis showed no effect of the supplementation applied on the muscle tissue fat and protein content (Table 6). On the other hand, the supplementation was found to have exerted a significant effect on the dry matter content, significantly lower in the supplemented rats compared to the rats fed the non-supplemented modified diet. The effect was evident despite a higher concentration of both protein and fat in the muscle tissue of the females kept on the supplemented diet. The effect observed could be indicative of an increase in the tissue water content in the two supplemented groups. The amount of ash produced by the muscle tissue combustion was significantly higher in the two supplemented groups than that in the non-supplemented rats. The complementary supplementation group showed a higher amount of ash than the excess supplementation rats, despite the fact that the muscle tissue of the latter contained more minerals analysed, in terms of both absolute and relative (referred to unit dry weight) values (Table 6). The effect may suggest an influence of the supplementation applied on absorption, metabolism, and excretion of minerals other than those studied.

The blood serum concentration of calcium and, to a lesser extent, phosphorus are very precisely regulated by three organs: the kidneys, the bones, and the small intestine, and by three hormones affecting these organs: parathormone, calcitonin, and $1.25(\mathrm{OH})_{2} \mathrm{D}_{3}$.

Analysis of the calcium supplementation applied on the blood serum calcium concentration revealed 
Friedrich, M., Podlaszewska, G., Pokorska-Niewiada, K. (2015). Effects of complementary and excess diet supplementation with selected minerals on their metabolism and distribution in the body: a model study. Acta Sci. Pol. Technol. Aliment., 14(2), 165-174. DOI: 10.17306/J.AFS.2015.2.18

Table 6. Effects of diet type and type of supplementation on female rat body composition $(\mathrm{x} \pm \mathrm{SD}, \mathrm{n}=44)$

\begin{tabular}{lccccc}
\hline $\begin{array}{c}\text { Component } \\
\%\end{array}$ & $\begin{array}{c}\text { Basic feed } \\
\text { (a) }\end{array}$ & $\begin{array}{c}\text { Modified feed } \\
\text { (b) }\end{array}$ & $\begin{array}{c}\text { Modified feed } \\
\text { supplementation } \\
\text { (c) }\end{array}$ & $\begin{array}{c}\text { Modified feed } \\
\text { supplementation } \\
\text { (d) }\end{array}$ & $\begin{array}{c}\text { Significance of } \\
\text { difference }\end{array}$ \\
\hline Protein & $23.1 \pm 1.08$ & $22.9 \pm 0.21$ & $23.1 \pm 0.21$ & $22.7 \pm 0.16$ & - \\
Fat & $2.43 \pm 0.14$ & $2.44 \pm 0.24$ & $2.59 \pm 0.21$ & $2.41 \pm 0.08$ & - \\
Dry matter & $27.9 \pm 0.53$ & $28.1 \pm 0.14$ & $27.2 \pm 0.35$ & $27.5 \pm 0.52$ & a,c, d-b* \\
Ash & $1.27 \pm 0.03$ & $1.28 \pm 0.08$ & $1.45 \pm 0.03$ & $1.39 \pm 0.05$ & a-c, d** \\
& & & & & b-c, d** \\
\hline
\end{tabular}

$*$,**Differences significant at $\mathrm{p} \leq 0.05$ and $\mathrm{p} \leq 0.01$, respectively.

a significant effect of the complementary supplementation only (Table 7). Calcium concentration in the blood serum of the rats fed a diet with complementary calcium supplementation was observed to increase, and was significantly higher than that observed in the non-supplemented groups, but did not reached even the lower limit of the reference values for the Wistar rats (Wang-Fisher and Koetzner, 2008). The increased blood serum calcium concentration in the supplemented females was accompanied by a significant (compared to that of the standard feed-kept rats) increase of the inorganic phosphorus concentration to above the upper reference level. Changes in the blood serum calcium and phosphorus concentrations were accompanied by a significant reduction, in the excess supplementation group, of alkaline phosphatase activity, compared to other groups, as well as by a significant reduction in calcitonin concentration in the excess supplementation group, compared to the complementary supplementation treatment. In addition, there was a non-significant increase in the hormone concentration in the complementary supplementation group (Table 9).

However, the supplementation applied increased, albeit non-significantly, the muscle calcium content compared to the contents recorded in muscles of those females kept on the modified non-supplemented diet where the diet modification significantly reduced the calcium content compared to that in females fed the standard feed (Table 8). The supplemented groups showed unchanged calcium excretion with urine. It should be noted, however, that the calcium excretion similarly to excretion of magnesium - was higher than that in the group fed the standard feed. Considering the time factor, it seems this could be important.
Analysis of calcium consumption by the females studied, particularly those receiving the excess supplementation treatment (Table 5) showed the excess calcium supply to not only failed to compensate for its deficiency at the blood level, but to also reduced a possibility of calcium inclusion into the bones, as indicated by the reduced calcitonin concentration. In addition, the calcium excess administered was not excreted with urine, and was not accumulated in muscles. Calcification of soft tissues, particularly of the placenta, can thus be the only explanation. This is a mere speculation, not confirmed by any dedicated study, but based on literature data which unequivocally show that such a possibility does exist (Karwowski and Naumnik, 2011; Willens et al., 2006).

Considering the significant reduction in the ALP activity in the rat group in question it seems that the excessive calcium supply reduced, by increasing the intestinal phosphorus absorption, calcium transport via osteoblast membranes, thus affecting bone demineralisation to some extent.

It also seems that the lack of increase - in fact a reduction - of calcitonin concentration in the excess supplementation group may suggest that this clockwork-precision mechanism was derailed by the supplementation. That this was the case should be also suggested by the absence, in the supplemented groups, of changes in magnesium concentrations in the blood serum and in the muscle tissue, accompanied by increased magnesium excretion with urine.

The experiment described showed no effect of the diet composition change per se on the bone calcium concentration. Taking into account the calcium homeostasis mechanism in the blood, it is not surprising. 
Friedrich, M., Podlaszewska, G., Pokorska-Niewiada, K. (2015). Effects of complementary and excess diet supplementation with selected minerals on their metabolism and distribution in the body: a model study. Acta Sci. Pol. Technol. Aliment., 14(2), $165-174$. DOI: 10.17306/J.AFS.2015.2.18

Table 7. Effects of diet and supplementation on levels of selected minerals in blood plasma and urine and content in the muscle tissue $(\mathrm{x} \pm \mathrm{SD}, \mathrm{n}=44)$

\begin{tabular}{|c|c|c|c|c|c|}
\hline Parameter & $\begin{array}{l}\text { Basic feed } \\
\text { (a) }\end{array}$ & $\begin{array}{l}\text { Modified } \\
\text { feed } \\
\text { (b) }\end{array}$ & $\begin{array}{l}\text { Modified feed } \\
+ \text { fortification } \\
\text { (c) }\end{array}$ & $\begin{array}{l}\text { Modified feed } \\
+ \text { suplementation } \\
\text { (d) }\end{array}$ & $\begin{array}{l}\text { Significance of } \\
\text { differences }\end{array}$ \\
\hline \multicolumn{6}{|l|}{ Blood plasma } \\
\hline Calcium, mmol/1 & $2.48 \pm 0.08$ & $2.49 \pm 0.11$ & $2.60 \pm 0.10$ & $2.52 \pm 0.12$ & $\mathrm{c}-\mathrm{a}, \mathrm{b}^{*}$ \\
\hline Magnesium, mmol/1 & $1.03 \pm 0.09$ & $1.00 \pm 0.06$ & $1.05 \pm 0.09$ & $1.08 \pm 0.08$ & - \\
\hline Phosphorus, mg/dl & $5.41 \pm 0.64$ & $5.75 \pm 0.39$ & $6.24 \pm 0.49$ & $6.26 \pm 0.55$ & $\begin{array}{l}\text { d-a** } \\
c-a^{* *}\end{array}$ \\
\hline \multicolumn{6}{|l|}{ Urine } \\
\hline Calcium, mmol/24 h & $0.056 \pm 0.031$ & $0.071 \pm 0.027$ & $0.065 \pm 0.015$ & $0.068 \pm 0.014$ & - \\
\hline Magnesium, mmol/24 h & $0.111 \pm 0.040$ & $0.127 \pm 0.022$ & $0.141 \pm 0.026$ & $0.134 \pm 0.029$ & - \\
\hline \multicolumn{6}{|l|}{ Muscle tissue } \\
\hline Calcium, $\mu \mathrm{g} / \mathrm{g}$ & $67.3 \pm 16.5$ & $52.5 \pm 4.2$ & $58.9 \pm 14.9$ & $59.6 \pm 7.9$ & $a-b^{* *}$ \\
\hline Magnesium, $\mu \mathrm{g} / \mathrm{g}$ & $276.9 \pm 11.1$ & $277.6 \pm 7.2$ & $277.7 \pm 9.2$ & $282.8 \pm 9.6$ & - \\
\hline Zinc, $\mu \mathrm{g} / \mathrm{g}$ & $11.4 \pm 2.06$ & $10.6 \pm 1.45$ & $11.1 \pm 1.98$ & $11.7 \pm 2.39$ & - \\
\hline Chromium, $\mu \mathrm{g} / \mathrm{g}$ & $0.029 \pm 0.004$ & $0.030 \pm 0.003$ & $0.037 \pm 0.004$ & $0.032 \pm 0.003$ & $\begin{array}{c}\mathrm{c}-\mathrm{a}, \mathrm{b}^{* *}, \mathrm{~d}^{*} \\
\mathrm{~d}-\mathrm{a}^{*}\end{array}$ \\
\hline
\end{tabular}

$*, * *$ Difference significant at $\mathrm{p} \leq 0.05$ and $\mathrm{p} \leq 0.01$, respectively.

Tabla 8. Effects of diet type and type of supplementation on the content of choren mineral components in muscle tissue of female rats per $100 \mathrm{~g}$ dray mass $(\mathrm{x} \pm \mathrm{SD}, \mathrm{n}=44)$

\begin{tabular}{lccccc}
\hline $\begin{array}{c}\text { Parameters } \\
\mu \mathrm{g}\end{array}$ & $\begin{array}{c}\text { Basic feedstuff } \\
\text { (a) }\end{array}$ & $\begin{array}{c}\text { Modified } \\
\text { feedstuff } \\
\text { (b) }\end{array}$ & $\begin{array}{c}\text { Modified feedstuff } \\
\text { supplementation } \\
\text { (c) }\end{array}$ & $\begin{array}{c}\text { Modified feedstuff } \\
\text { supplementation } \\
(\mathrm{d})\end{array}$ & $\begin{array}{c}\text { Significant } \\
\text { difference }\end{array}$ \\
\hline Calcium & $241.2 \pm 36.8$ & $186.8 \pm 16.2$ & $216.5 \pm 52.3$ & $216.7 \pm 24.3$ & a-b** \\
Magnesium & $992.0 \pm 42.8$ & $987.9 \pm 30.2$ & $1020.9 \pm 30.8$ & $1028.4 \pm 31.1$ & - \\
Zinc & $40.86 \pm 8.3$ & $37.7 \pm 5.2$ & $40.81 \pm 8.1$ & $42.54 \pm 8.6$ & - \\
Chromium & $0.1039 \pm 0.0015$ & $0.1068 \pm 0.0011$ & $0.1360 \pm 0.0014$ & $0.1164 \pm 0.0012$ & $\begin{array}{c}\mathrm{a}-\mathrm{c}^{* *}, \mathrm{~d}^{*} \\
\mathrm{~b}-\mathrm{c}^{* *}, \mathrm{c}^{*}\end{array}$ \\
\hline
\end{tabular}

$*, * *$ Significant difference $\mathrm{p} \leq 0.05 ; 0.01$.

On the other hand, the change in diet composition significantly affected the muscle calcium content. The reduced calcium consumption by those females fed the modified non-supplemented diet was reflected in the significant decrease of the muscle tissue calcium concentration, which is consistent with results reported by other authors (Dawson-Hughes et al., 2003). In addition, considering the calcium excretion with urine, increased albeit non-significantly so, as well as the slight increase in the calcitonin concentration, it 
Friedrich, M., Podlaszewska, G., Pokorska-Niewiada, K. (2015). Effects of complementary and excess diet supplementation with selected minerals on their metabolism and distribution in the body: a model study. Acta Sci. Pol. Technol. Aliment., 14(2), 165-174. DOI: $10.17306 / J . A F S .2015 .2 .18$

Table 9. Effects of diet type and type of supplementation on ALP activity and calcitonin concentration in female rat blood plasma $(\mathrm{x} \pm \mathrm{SD}, \mathrm{n}=44)$

\begin{tabular}{lccccc}
\hline \multicolumn{1}{c}{ Parameter } & $\begin{array}{c}\text { Basic feed } \\
\text { (a) }\end{array}$ & $\begin{array}{c}\text { Modified feedf } \\
\text { (b) }\end{array}$ & $\begin{array}{c}\text { Modified feed } \\
\text { supplementation } \\
\text { (c) }\end{array}$ & $\begin{array}{c}\text { Modified feed } \\
+ \text { supplementation } \\
\text { (d) }\end{array}$ & $\begin{array}{c}\text { Significance of } \\
\text { difference }\end{array}$ \\
\hline ALP, U/L & $46.1 \pm 18.3$ & $44.1 \pm 16.2$ & $45.8 \pm 16.6$ & $37.3 \pm 8.3$ & - \\
Calcitonin, IU/ml & $8.10 \pm 3.38$ & $9.77 \pm 3.53$ & $10.78 \pm 7.21$ & $5.64 \pm 4.37$ & c-d* $^{*}$ \\
\hline
\end{tabular}

$*, * *$ Differences significant at $\mathrm{p} \leq 0.05$ and $\mathrm{p} \leq 0.01$, respectively.

may be suggested that the maintenance of an appropriate concentration of calcium in the blood serum of the females in question could have been effected at the expense of calcium reserves in bones, but also in muscles.

The experiment revealed no significant influence of either the change in diet composition or diet supplementation on the magnesium concentration in the blood serum and muscle tissue and excretion with urine. Considering, however, the magnitude of magnesium consumption by the rats (Table 5) it can be contended that the change in diet composition and the halved magnesium consumption must have set mechanisms of magnesium release from bones in motion.

The females studied showed no significant effect of the change in diet composition and supplementation on the muscle zinc content. Considering the magnitude of zinc consumption and its content in muscles (per unit dry weight), it can be remarked that, at the 12 and 94\% increase in the supplemented groups, the zinc content did increase, and was higher by 8 and $13 \%$ than the content in rats kept on the modified nonsupplemented diet. This is indicative of limits of zinc deposition in muscles. This is also consistent with results of studies which demonstrated, within physiological limits, a direct relationship between the magnitude of supplemented zinc dose and zinc concentrations in the blood, brain tissue, muscles, and other tissues (Mazurek-Machol and Machoy-Mokrzyńska, 2005).

Analysis of effects of diet composition change and supplementation on chromium content in the muscle tissue revealed the complementary supplementation only to have resulted in a significant increase of the chromium content, compared to both the standard and the modified diet. The excess supplementation produced a significant increase in the muscle chromium content only when compared to the females kept on the standard diet, the chromium content being significantly lower than that in the females fed the complementary supplementation feed. Therefore it seems that chromium uptake exceeding the indispensable amount is useless, the more so that an increase in the muscle chromium content does not lead to reduction of the muscle tissue fat content. However, with respect to the females examined, effects of a higher uptake of zinc and its inhibition of chromium absorption cannot be ruled out.

No effect of diet modification per se on the muscle tissue chromium content was found.

Analysis of all the changes occurring as a result of supplementation of the diet modified by substituting a part of the whole wheat and corn grains with white flour and sucrose showed that not all the changes were favourable and beneficial for the females studied. This was particularly true with respect to the reduced uptake of feed, and thus of the basic nutrients, other than the dietary supplements, which control inadequately low body weight gains per unit feed consumed, accumulation of perivisceral adipose tissue, increase magnesium excretion with urine, and seemingly disturbed hormonal mechanisms of a key importance for metabolic homeostasis of a mineral.

Some of the changes observed could have been a result of, i.a., antagonism in absorption and metabolism of the minerals applied. However, the type and amounts of the minerals were mimicking the available dietary formulations to, similarly to the diet modification, simulate to some extent the supplementation pattern of human diets.

In this context, effects of the diet modification per se, resulting in a more refined foods lacking certain minerals seem to be less adverse, which lends support to the view that, within a certain range of mineral deficiencies, 
Friedrich, M., Podlaszewska, G., Pokorska-Niewiada, K. (2015). Effects of complementary and excess diet supplementation with selected minerals on their metabolism and distribution in the body: a model study. Acta Sci. Pol. Technol. Aliment., 14(2), $165-174$. DOI: 10.17306/J.AFS.2015.2.18

the body maintains the homeostasis of mineral concentrations without much harm for metabolic pathways.

\section{CONCLUSIONS}

Analysis of the results allowed to conclude that:

1. Except for chromium, contents of the selected minerals in the tissues examined and urea as well as concentrations of calcitonin and alkaline phosphatase (ALP) activities did not point to any significant effect of the supplementation applied on the body contents of those minerals.

2. Effects observed as the accumulation of perivisceral, epicardial and intramuscular adipose tissue, as well as increased body weight increments, could have been related to disturbed proportions of the minerals supplemented, their synergy and antagonism and, consequently, a potential generation of secondary deficiencies and excesses which could significantly affect individual metabolic pathways.

3. The intensity of changes observed was generally higher in the females receiving complementary supplementation, although their uptake of minerals studied was similar to that shown by the females kept on the basic diet.

\section{REFERENCES}

Anderson, R. A. (1998). Effects of chromium on body composition and weight loss. Nutr. Rev., 56, 9, 266-270.

Balk, E. M., Eatsioni, A., Lichtenstein, A. H., Lau, J., Pitas, A. G. (2007). Effect of chromium supplementation on glucose metabolism and lipids: a systematic review of randomized controlled trials. Diab. Care, 30, 2154-2163.

Bolesławska, I., Maruszewska, M., Przysławski, J. (2005). Intake of selected nutrients present in daily food rations $(\mathrm{DFR}, \mathrm{s})$ taken by males and females from Wielkopolska Region. Now. Lek., 4 (74), 366-368.

Comhair, S. A., Erzurun, S. C. (2005). The regulation and role of extracellular glutathione peroxidase. Antioxid. Redox. Signal., 7, 102, 72-79.

Dawson-Hughes, B., Harris, S. S., Krall, E. A. (2003). Effect of calcium and witamin D supplementation on bone density in men and women 65 years of age or older. N. Engl. J. Med., 327, 1637-1642.

Friedrich, M., Goluch-Koniuszy, Z., Dolot, A., Pilarczyk, B. (2011). Appreciation of selenium concentration in blond and tissues of male rat as a results of diet ingredient changes and its supplementation with chosen group B vitamins. Rocz. PZH, 62, 41-46.

Gawęcki, J. Jeszka, J. (1995). Żywienie człowieka [Human nutrition]. Warszawa: PWN.

Heaney, R. P., Davies, K. M., Barger-Lux, M. J. (2003). Calcium and weight: clinical studies. J. Am. Coll. Nutr., 21, 2, 1528-1558.

Joseph, P., He, Q., Umbright, C. (2008). Heme oxygenase 1 gene expression in marker forhexavalent chromium induced stress and toxicity in human dermal fibroblasts. Toxicol. Sci., 103, 2, 325-334.

Karwowski, W., Naumnik, B. (2011). Blood vessel calcification - interdisciplinary problem. Forum Nefrol., 4, 2, 91-99.

Kunachowicz, H., Troszczyńska, A. (2005). Fortified foods, vitamin and mineral supplements and their role in regular diet. Now. Lek., 4 (74), 533-538.

Lorenzen, J., Mølqaard, C., Michelsen, K. F., Astrup, A. (2006). Calcium supplementation for $1 \mathrm{y}$ does weight or fat mass in young girls. Am. J. Clin. Nutr., 1 (83), 18-23.

Lukaski, H. C., Siders, W. A., Penland, J. G. (2007). Chromium picolinate supplementation in women: effects on body weight, composition and iron status. Nutrition, 23, 3, 187-195.

Mazurek-Mochol, M., Machoy-Mokrzyńska, A. (2005). The level of zinc in the blood, urine, bones and teeth of rats following intra-oral application of this element. Czas Stom., 58, 3, 194-200.

Olusi, S. (2002). Obesity is an independent risk factor plasma lipid peroxidation and depletion of erythrocyte cytoprotetic enzymes in humans. Int. J. Obes. Relat. Metab. Disord., 9 (26), 1159-1164.

Podlaszewska, G., Friedrich, M., Sadowska, J. (2009). The estimation of the effect of diet composition and its supplementation with chosen mineral elements on the concentration of corticosterone and the waters balance at male rats. Żywn. Nauka Techn. Jakość, 4 (65), 345-351.

Directive 1925/2006 of the European Parliament and Council of 20 December 2006 Minister of Health in Directive of 16 September 2010. (2010). Dz.U. nr 136, poz. 914.

Steinbrenner, H., Bilgic, E., Alili, L., Sies, H. (2006). Selenoprotein $\mathrm{P}$ protects endothelial cells from oxidative damage by stimulation of glutathione peroxidase expression and activity. Free Rad. Res., 9 (90), 936-943.

Szponar, L., Stoś, K. (2004). Food supplements - the possibilities of their use for prevention of some dietary deficiencies. Żyw. Człow. Metab., 31 (supl. 1), 441-446.

Wang-Fisher, Y., Koetzner, L. (2008), Common biochemical and physiological parameters in rats. In Y. Wang-Fisher (Ed.), Manual of stroke models in rats (pp. 315-323). CRC Press. 
Friedrich, M., Podlaszewska, G., Pokorska-Niewiada, K. (2015). Effects of complementary and excess diet supplementation with selected minerals on their metabolism and distribution in the body: a model study. Acta Sci. Pol. Technol. Aliment., 14(2), 165-174. DOI: 10.17306/J.AFS.2015.2.18

Willens, H. J., Chirinos, J. A., Schob, A., Veerani, A., Perez, A. J., Chakko S. (2006). The relation between mitral annular calcification and morality in patients undergoing diagnostic coronary angiography. Echocardiography, $23,717-722$
Van Soest, P. J., Wine, R. H. (1967). Use of detergens in the analysis of fibrous Leeds. IV: Determination of plant cell-wall constituens. JAOAC, 50, 50-51.

Zieliński, H., Achremowicz, B., Przygodzka, M. (2012). Antioxidants cereal grains. Żywn. Nauka Techn. Jakość, $1,(80), 5-26$.

\section{OCENA WPtYWU UZUPEtNIAJĄCEGO I NADMIAROWEGO DODAWANIA DO DIETY WYBRANYCH SKŁADNIKÓW MINERALNYCH NA ICH METABOLIZM I DYSTRYBUCJĘ W ORGANIZMIE - BADANIA MODELOWE}

\section{STRESZCZENIE}

Wprowadzenie. Celem pracy było określenie, na modelu zwierzęcym, wpływu uzupełniania diety - w której pełne ziarna pszenicy i kukurydzy zastąpiono białą mąką i sacharozą, wapniem, magnezem, cynkiem i chromem - na ich metabolizm i dystrybucję w organizmie.

Materiat i metody. Badania przeprowadzono na czterech grupach samic szczura szczepu Wistar $(\mathrm{n}=11)$. Poszczególne grupy żywiono: paszą standard zawierającą m.in. pełne ziarna pszenicy i kukurydzy (grupa I); paszą zmodyfikowaną, w której w stosunku do paszy standard, około $84 \%$ pełnych ziaren pszenicy zastąpiono mąka pszenną typ 500, a 50\% obecnej w niej kukurydzy - sacharozą (grupa II); paszą zmodyfikowaną, suplementowaną w sposób uzupełniający powstałe po zamianie składników diety niedobory $\mathrm{Ca}, \mathrm{Mg}, \mathrm{Zn}$ i Cr (grupa III) oraz paszą zmodyfikowaną, suplementowaną tymi samymi składnikami mineralnymi, ale w sposób nadmiarowy, przekraczający od 0,5 do 3 razy niedobory powstałe po zamianie składników diety (grupa IV). Zastosowana zamiana obecnych w diecie pełnych ziaren zbóż na białą mąkę i sacharozę oraz jej uzupełnianie składnikami mineralnymi mogły imitować, do pewnego stopnia, współczesny sposób odżywiania i stosowane w technologii żywności wzbogacanie, a suplementacja nadmiarowa - aktualne zachowania różnych grup ludności.

Wyniki. Obie formy uzupełniania powodowały istotny wzrost zawartości okołonarządowej tkanki tłuszczowej, niewpływając na jej zawartość w tkance mięśniowej. Zastosowane uzupełnianie nie zmieniało zawartości wapnia, magnezu i cynku w mięśniach, nie zwiększało też istotnie wydalania wapnia i magnezu z moczem, ale zmiany aktywności ALP i stężenia kalcytoniny nie wskazywały na możliwość deponowania ich w tkance kostnej.

Wnioski. Analiza uzyskanych wyników pozwoliła na następujące stwierdzenia: 1) zawartość wybranych składników mineralnych w badanych tkankach i moczu oraz stężenie kalcytoniny i aktywność fosfatazy alkalicznej (ALP) nie wykazały, poza chromem, istotnego wpływu zastosowanych suplementacji na ich zawartość w ustroju; 2) obserwowane efekty w postaci gromadzenia wisceralnej, nasierdziowej i śródmięśniowej tkanki tłuszczowej oraz zwiększone przyrosty masy ciała mogły być związane z zaburzeniami wzajemnych proporcji suplementowanych składników mineralnych, ich synergizmem i antagonizmem, i w związku z tym, możliwością powstawania wtórnych niedoborów i nadmiarów, istotnie wpływających na określone tory metaboliczne; 3 ) natężenie zachodzących zmian było generalnie większe w grupach zwierząt suplementowanych w sposób uzupełniający, pomimo że wielkość spożycia badanych składników mineralnych była zbliżona do spożycia w grupie na paszy standard.

Słowa kluczowe: suplementacja, składniki mineralne, metabolizm, samice szczura

For citation - Do cytowania

Friedrich, M., Podlaszewska, G., Pokorska-Niewiada, K. (2015). Effects of complementary and excess diet supplementation with selected minerals on their metabolism and distribution in the body: a model study. Acta Sci. Pol. Technol. Aliment., 14(2), $165-174$. DOI: $10.17306 / J . A F S .2015 .2 .18$ 